\title{
Traditional and Pharmacological Reports of The Genus Baccaurea. A Review
}

\author{
Tasnia Khasru Charu, Nargis Sultana Chowdhury*, Ismat Benta Fatema, Farjana Islam Liya \\ and Lubaba Salsabil
}

Department of Pharmacy, Manarat International University, Bangladesh

*Corresponding author: Nargis Sultana Chowdhury, Department of Pharmacy, Manarat International University, School of Engineering, Science and Technology, Ashulia Model Town, Bangladesh.

To Cite This Article: Tasnia Khasru Charu, Nargis Sultana Chowdhury, Ismat Benta Fatema. Traditional and Pharmacological Reports of The Genus Baccaurea. A Review. Am J Biomed Sci \& Res. 2021 - 11(6). AJBSR.MS.ID.001683. DOI: 10.34297/AJBSR.2021.11.001683.

Received: 阱 December 8, 2020; Published: 眥 February 03, 2021

\begin{abstract}
Baccaurea is a genus of flowering plant belongs to the family Phyllanthaceae categorically large genus with members of up to 100 species and few of which have been recognized as popular healing plants in South-East Asia. (B. ramiflora), (B. angulata), (B. courtallensis), (B. macrophylla), (B. macrocarpa), (B. lanceolata), (B. racemosa) and (B. motleyana) are underutilized medicinal plants of the genus Baccaurea. The literature review revealed that Baccaurea species have been used traditionally in South-East Asian countries to treat various diseases. Baccaurea species have been believed to possess significant medicinal values like analgesic, anthelmintic, antioxidant, anti-diarrheal, antiatherosclerotic, anticancer, antidiabetic, neuropharmacological, thrombocytic, antimicrobial, etc. activities. Few species of the Baccaurea genus have demonstrated significant exposure to phytochemicals such as alkaloids, flavonoids, anthocyanins, carotenoids, tannins, phytosterols, saponins, phenolic compounds, steroids, rosmarinic acids, etc. Several bioactive constituents including 6'-0-vanilloylpicraquassioside D, 4'-0-(6-0-vanilloyl)- $\beta$-D-glucopyranosyl tachioside D, Icariside B5, picrotoximaesin, $\beta$-sitosterol, Sapidolide A, Daucosterol, methyl 2-hydroxy-3-methylbutanoate, quercetin, decanoic acid, etc. were also isolated and described from various species of Baccaurea. The purpose of this review is to evaluate the published article which is based on the medicinal values of different species of Baccaurea genus, provide updated information and knowledge on the ethnomedicinal, pharmacological and phytochemical properties and further phytochemical assessment opens a new prevalence, effectiveness in protection and clinical research.
\end{abstract}

Keywords: Baccaurea, Traditional, Pharmacological, Phytochemicals, Effectiveness, Alkaloids, Flavonoids, Anthocyanins, Carotenoids, Tannins, Phytosterols, Saponins, Phenolic Compounds, Steroids, Rosmarinic

\section{Introduction}

Plants and phytoproducts continue to play a vital role in the treatment of various diseases. From the beginning of human civilization, plants have beneficial activity in the treatment of human diseases. World Health Organization (WHO) survey reveals that about $80 \%$ of the world's inhabitant's problem is treated by medicinal herbal drug for their primary health care [1]. Nowadays, the use of medicinal plants for alleviating diseases is growing day by day around the world especially in Asia [2]. Drug discovery from plants is a multi-disciplinary approach and is interconnected with many disciplines like botanical, ethnobotanicals, phytochemical, biological, and various chemical separation processes along with combinatorial synthetic techniques [3]. Although pharmaceuticals derived from flowering plants still account for almost 30\% of the prescribed items, modern orthodox. Western medicine over the last century has moved away from an obvious connection with plants [4]. In many other parts of the world herbalism flourishes as the standard method of treatment [5]. Among plants, the genus of Baccaurea have interesting biological activities. Baccaurea is a genus of flowering plant belonging to the family Phyllanthaceae. The genus comprises about 100 species, extensively distributed from Indo-Malaysia to the West Pacific [6].

Among them, few species of Baccaurea namely Baccaurea ramiflora Lour Baccaurea sapida Muell.Arg (B. ramiflora), Baccaurea angulata (B. angulata), Baccaurea courtallensis Muell. Arg. (B. 
courtallensis), Baccaurea macrocarpa (B. macrocarpa), Baccaurea macrophylla Muell (B. macrophylla), Baccaurea lanceolata (B. lanceolata), Baccaurea racemosa Müll.Arg (B. racemosa), and Baccaurea motleyana (B. motleyana) are available in the south-east Asian region. According to ethanobotanical and traditional uses, these flowering plants are used for rheumatoid arthritis, cellulitis, abscesses, treat injuries, constipation, treatment of infectious diseases such as diarrhoea, dysentery, and skin infection, sore eyes etc. [7]. Plants of Baccaurea species have been shown to contain diverse phytochemical properties like phytosterols, saponins, flavonoids, steroids, phenolic compounds, tannins, volatile oils, etc. [7-8]. Different pharmacological studies including antioxidant, antimicrobial, cytotoxic, anti-inflammatory, anticancer, haemolytic, neuropharmacological, insecticidal, etc. on this Baccaurea species. Considering the secret potentialities of the underutilized Baccaurea species, so far, several research studies have been carried out to investigate their different medicinal uses, demand the isolation and detection of active concepts and comprehensive bioassay.

\section{Baccaurea Species in Folklore Practice}

Generally, the practice of herbal medicine is most widespread in developing countries and is often more affordable than expensive modern pharmaceutical drugs [9]. It has been revealed that $80 \%$ of the population in Asian countries are still using herbal medicines as their main medicinal source for their wellbeing [10].

B. ramiflora, the most well-known species, for the Southeast Asian region and found growing wild as well as under cultivation in Nepal, Bangladesh, India, Myanmar, South China, Indochina, Thailand, the Andaman Islands and Peninsular Malaysia. It grows in few districts of Bangladesh namely Narsingdi, Sylhet, Gazipur, Netrokona and Kishoregonj [11]. The folklore uses of B. ramiflora have attracted the attentions over time and thus various researchers documented different parts of species are used as ethnomedical for many purposes like as an anti-phlogistic and anodyne against rheumatoid arthritis, cellulitis, abscesses, indigestion, flavouring and colouring agent etc. by the inhabitants of different countries in Southeast Asia [Table 1]. B. courtallensis is another common species widely distributed in Western Ghats of India [12]. The plant is frequently used in India such as treatment of diarrhoea, dysentery, skin infection, controlling diabetes, piles, antidote, anti-inflammatory purposes etc. International Union for Conservation of Nature and Natural Recourses (IUCN) has enlisted it as threatened species [13].

Table 1: Folklore/Traditional uses of underutilized fruits of Baccaurea genus.

\begin{tabular}{|c|c|c|c|c|}
\hline Species & Local Name & Used Part & Uses & References \\
\hline \multirow{5}{*}{$\begin{array}{l}\text { B. ramiflora Lour. } \\
\text { Muell-Arg }\end{array}$} & \multirow{5}{*}{$\begin{array}{l}\text { Latka/Latkan/lotko/ } \\
\text { Notko/Anshfol. }\end{array}$} & Whole plant & $\begin{array}{l}\text { An antiphlogistic and anodyne against rheumatoid arthritis, cellulitis, } \\
\text { abscesses and to treat injuries in Chinese Dai medicine. Also used for } \\
\text { stomach ulcer, stomachache and colic in Mizoram, India. Used against } \\
\text { some ailments by hill-tribes in Northern Thailand. }\end{array}$ & [18-20] \\
\hline & & Fruit & $\begin{array}{c}\text { Religious purpose as applied by Local people during the Holy Chariot } \\
\text { Procession of Lord Jagannath. People pay their homage to God by throw- } \\
\text { ing the latka fruit along with other rituals. The Fruit juice is considered as } \\
\text { an Antidote for snake bite in Assam, India. }\end{array}$ & [21-22] \\
\hline & & Young leaves & $\begin{array}{l}\text { Used as vegetable, flavoring agent with curries and minced meat in } \\
\text { Bangladesh. }\end{array}$ & {$[23]$} \\
\hline & & Bark & $\begin{array}{c}\text { In India, fresh bark is chewed or juice is used orally for constipation. } \\
\text { Stem bark gives diuretic activity. }\end{array}$ & {$[24]$} \\
\hline & & Seed & $\begin{array}{l}\text { Seeds are crushed to cure diarrhea. In Bangladesh, cultivated chiefly for } \\
\text { production of valuable dye called annatto which is used for colouring silk, } \\
\text { cotton, and other textile materials for orange colour. }\end{array}$ & [25-26] \\
\hline \multirow{6}{*}{$\begin{array}{l}\text { B. courtallensis } \\
\text { (Wight) Muell. } \\
\text { Arg. }\end{array}$} & \multirow{6}{*}{$\begin{array}{l}\text { Mootapalam/ Mut- } \\
\text { tithuri/ Kalikuki/ } \\
\text { Muttathuri. }\end{array}$} & Root and leave & $\begin{array}{c}\text { The paste of root and leaves are mixed with hot water and taken internal- } \\
\text { ly to treat piles and act as antidote. }\end{array}$ & {$[27]$} \\
\hline & & Fruit & $\begin{array}{l}\text { Local tribal people such as kanikkar, Malampandarangal and Paniyar } \\
\text { consume ripe fruit for its medicinal properties. Treatment for sterility, } \\
\text { mouth, and stomach ulcers and for controlling serum cholesterol degree. }\end{array}$ & {$[12,28]$} \\
\hline & & Root & Used in the treatment of controlling diabetes and headache. & [12] \\
\hline & & Fruit rind & $\begin{array}{l}\text { In Kerala, fruit rind is pickled for use in everyday life. The pericarp of } \\
\text { tender fruit is consumed as antipyretic. }\end{array}$ & {$[27,29]$} \\
\hline & & Leave & $\begin{array}{l}\text { In Kerala, boiled water of fruits, bark and leaves powder form is taken in- } \\
\text { ternally to take out poison traditionally. The fresh leaves paste is applied } \\
\text { on swellings for anti-inflammatory purposes. Leaves are cooked like side } \\
\text { dishes and consumed with rice or rice soup. }\end{array}$ & [30-31] \\
\hline & & Bark & $\begin{array}{l}\text { The bark is used as a tonic in disorders of mucous membrane and to heal } \\
\text { wounds and antibacterial recreation. }\end{array}$ & {$[32]$} \\
\hline
\end{tabular}




\begin{tabular}{|c|c|c|c|c|}
\hline \multirow{4}{*}{$\begin{array}{l}\text { Baccaurea angula- } \\
\text { ta Merr }\end{array}$} & \multirow{4}{*}{$\begin{array}{l}\text { Belimbing Dayak/ } \\
\text { Belimbing hutan. }\end{array}$} & Skin & The red part (skin) is sour, and usually cooked by the rural communities. & [33] \\
\hline & & Whole fruit & $\begin{array}{l}\text { Eaten fresh and used in cooking and as traditional medical practice. } \\
\text { Aqueous juice of the whole fruit in daily meal also recommends. }\end{array}$ & {$[34-35]$} \\
\hline & & Berry & The soft whitish part of this fruit (berry) is edible. & [15] \\
\hline & & Extract gel & Good dental gel for wound healing in extracting a tooth. & [36] \\
\hline \multirow{4}{*}{$\begin{array}{l}\text { Baccaurea lanceo- } \\
\text { lata (Miq.) Muell. } \\
\text { Arg }\end{array}$} & \multirow{4}{*}{ Lepeso/Limposu } & Fruit & $\begin{array}{l}\text { In Iban community, the solution obtained from the fruits as a component } \\
\text { of an herbal formulation with other plant extracts, i.e., Etlingera elatior } \\
\text { (fruits) and Begonia spp (leaves) applied on head when it was cooled } \\
\text { to cure headaches. Fruits are potential to be used for the treatment of } \\
\text { fever (due to infection), swellings on the body and topically on the skin to } \\
\text { protect the skin from sunburn with natural skin care ingredients by the } \\
\text { Bidayuh people. }\end{array}$ & [37-39] \\
\hline & & Leave & $\begin{array}{l}\text { The decoction of leaves and water pounded in bamboo is used orally to } \\
\text { treat stomach-ache for medicinal purpose in Sarawak, Bidayuh commu- } \\
\text { nity. }\end{array}$ & [38] \\
\hline & & Bark & $\begin{array}{l}\text { To prevent drunkenness, the Penan community pound the bark and drink } \\
\text { the sap before consuming alcohol. }\end{array}$ & [39] \\
\hline & & Fruit shell & The shell of the fruit is eaten to cure diarrhea in the Kelabit community. & [10] \\
\hline $\begin{array}{l}\text { Baccaurea macro- } \\
\text { phylla Muell. }\end{array}$ & Langkha & Whole plant & $\begin{array}{l}\text { Used in in local cuisine and herbal medicines in Thailand. Treatment of } \\
\text { stomachache and sore eyes. }\end{array}$ & [17] \\
\hline \multirow{4}{*}{$\begin{array}{l}\text { Baccaurea motley- } \\
\text { ana Müll. Arg. }\end{array}$} & \multirow{4}{*}{ Rambai } & Bark & $\begin{array}{l}\text { The bark has been used as an ingredient of a concoction of many ingredi- } \\
\text { ents and administered internally after childbirth in protective medica- } \\
\text { ments. Squeezed cambium and inner bark has been used as remedy for } \\
\text { eye inflammation. }\end{array}$ & [40-41] \\
\hline & & Skin & $\begin{array}{l}\text { Used for sore eyes. In the Malaysian and Indonesian traditional cosmetic } \\
\text { industries, in medicated face powder preparation for treatment of acne } \\
\text { and general skin complaints. }\end{array}$ & [42] \\
\hline & & Fruit & The fruits are turned into a jelly and used for cooking. & [42] \\
\hline & & Peel & Induce abdominal discomfort. & [43] \\
\hline
\end{tabular}

B. angulata, is also the popular plant that is native to Borneo Island of Malaysia and several other regions of Indonesia [14]. The high antioxidant levels of $B$. angulata had opened a new possibility of developing it as herbal preparations that has a high potential for producing nutraceutical benefits our wellbeing. In Borneo Island, the plant is considered as traditionally important by the rural communities [15]. B. lanceolata, another species is found in Thailand, Peninsular Malaysia, Sumatra, Borneo, and Philippines. In traditional contemplation the plant is used for stomach-ache, body swellings, diarrhoea, prevent drunkenness, skin care ingredients etc. in South Kalimantan region [16]. B. motleyana species is popular to Thailand, Peninsular Malaysia, Sumatra, Java, Borneo, and Moluccas regions, which is used to treat as eye inflammation, childbirth protective medicaments, abdominal discomfort, cosmetic industries etc. by the local people in the Malaysian and Indonesian countries [16]. B. macrophylla is a species of fruit tree, which is native to Southeast Asia, especially East Kalimantan, Indonesia. Various parts of plants are used in local cuisine and herbal medicines in Thailand for treatment of stomachache and sore eyes as well as used as antiulcer and anti-inflammatory [17-25] (Table 1).

\section{Reported Pharmacological Activity}

\section{Antioxidant activity}

Medicinal plants have always been recognized as a potential source of natural antioxidants which are preventive compounds that play an important role in protecting against oxidative damage induced by Reactive Oxygen Species (ROS) [26-44]. Among Baccaurea species, B. ramiflora, B. angulata, B. courtallensis, B. macrocarpa, B. macrophylla, B. lanceolata, B. racemosa are reported to have antioxidant property. $B$. ramiflora is claimed to possess moderate antioxidant activity. To make an overall calculation of B. ramiflora's capacity for antioxidants several researchers have tried with the action of various solvents by using synthetic and natural antioxidants as standards. There are numerous studies for determining the antioxidant activity in terms of its aqueous, ethanolic, hydromethanol, methanolic and crude extracts of $B$. ramiflora, it can be suggested that the ethanolic extract of $B$. ramiflora leaf fractions presented better antioxidant potential (IC50 $4.524 \mu \mathrm{g} / \mathrm{ml}$ ) determined by (DPPH) radical scavenging assay, compared to other extracts [44-52]. Recent study indicated that the antioxidant activity of ethanolic, aqueous and crude extracts of leaf, root, and peel of $B$. courtallensis were evaluated through DPPH, FRAP, Hydroxyl radical scavenging activity and Nitric oxide assay by several researchers. Among them, B. courtallensis root crude aqueous extract showed effective scavenging abilities against the free radicals by acting as hydrogen donors to scavenge DPPH free radicals with (IC50 1.0 $\mu \mathrm{g} /$ $\mathrm{ml}$ ) [27-31]. The comparative study of another two underutilized fruits of Baccaurea genus, B. lanceolata and B. macrocarpa were in- 
vestigated for in vitro antioxidant properties, where it was found that B. macrocarpa (pericarp) showed the higher antioxidant activities than B. lanceolata in DPPH, ABTS and FRAP respectively [53].

The methanol extract of bark of B. macrocarpa has an antioxidant activity with (IC50 11.15ppm) [54]. Another investigation revealed that B. macrophylla dried leaf ethanolic extracts exhibited the highest antioxidant activities with (IC50 1.70 $\mathrm{g} / \mathrm{mL}$ ) [17]. Mining of literature showed a wide spectrum of antioxidant activities of different parts of $B$. rasemosa by using different solvents determined by (DPPH), (TEAC), (FRAP), and (ABTS) radical scavenging assays, whereas the methanolic leaf extract possessed highest activity (IC50 4.298 $\mu \mathrm{g} / \mathrm{ml}$ ) in DPPH radical scavenging assays [55-57]. Both in vitro and in vivo assays were performed using many antioxidant methods in B. angulata. Among them, methanolic peel extracts displayed the higher DPPH $(78.54 \pm 2.08 \mathrm{mg} \mathrm{AA} / 100 \mathrm{~g})$, indicating antioxidant activity [58-59]. B. angulata fruits was also examined in vivo antioxidant effect in rabbits, where Plasma malondialdehyde levels greatest in peel juice treated group (671.04\%), highest level of catalase activity (12.66 \%) and total antioxidant capacity $(309.08 \pm 35.59 \mathrm{mM})$ [34-35].

\section{Anti-microbial activity}

Anti-bacterial activity: In antimicrobial study, it was observed that the ethanol extract of $B$. angulata fruit showed the highest levels of antimicrobial activity with maximum inhibition $(37 \pm 1 \mathrm{~mm})$ using agar well diffusion against S. pneumonia [15]. Several researchers have been trying to make an overall antimicrobial estimate for potentiality of B. ramiflora (seed, stem bark, fruits) with the action of various solvents use against in many grams positive and gramnegative bacteria by disc diffusion method [46]. In this study, the methanolic extracts of $B$. ramiflora seed and fruits showed highest levels of antimicrobial activity with MIC $3.20 \mathrm{mg} / \mathrm{ml}$ against Staphylococcus aureus, Sarcina lutea and Shigella boydii [2] and fruits displayed MIC values ranging between 2.50 to $5.00 \mathrm{mg} / \mathrm{ml}$ against Staphylococcus aureus, Staphylococcus epidermidis, Shigella fexneri, Bacillus subtilis, Bacillus cereus and E. coli [60]. The stem bark $(400 \mu \mathrm{g} / \mathrm{ml})$ was the most effective against Shigella boydii with $25 \mathrm{~mm}$ zone of inhibition compared to the standard Ciprofloxacin $28 \mathrm{~mm}$ at $30 \mu \mathrm{g} / \mathrm{disc}$ [49]. The methanolic and benzene extracts $B$. courtallensis leaves exhibited significant antimicrobial activity in well diffusion method on Mueller-Hinton Agar (MHA) medium with MIC $1.6 \mu \mathrm{g} / \mathrm{ml}$ against B. Subtilis and $2.36 \mu \mathrm{g} / \mathrm{ml}$, against S. Aureus where Amoxicillin $(100 \mu \mathrm{g} / \mathrm{ml})$ disc isolates for comparison [61]. The comparative study of antimicrobial activity B. lanceolata fruit, leaves, and bark extracts was evaluated by using the disc diffusion method. Among them the fruits produced significant zones of inhibition in $\mathrm{mm}, 12.0$ for B. cereus and M. catarrhalis, 10.29 for P. acnes, respectively $[9,37]$. The ethanolic peel extract of $B$. motleyana was also demonstrated highest zone of inhibition of $35 \mathrm{~mm}$ against Proteus vulgaricus and Bacillus cereus and appeared to be as a good antimicrobial agent where streptomycin used as standard [40].

Anti-fungal activity: An experiment reported that, three compounds viz. sapidolide $A$, picrotoximaesin and ramifloside isolated from $B$. ramiflora berries showed antifungal activity

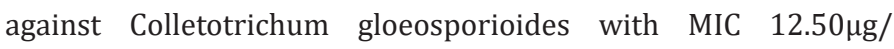
$\mathrm{ml}, 50.00 \mu \mathrm{g} / \mathrm{ml}$, and $12.50 \mu \mathrm{g} / \mathrm{ml}$, respectively compared to the standard carbendazim $(6.25 \mu \mathrm{g} / \mathrm{ml})$ [62]. The antifungal effect of B. sapida fruits due to presence of two isolated compounds, i.e., oleic acid and palmitic acid reveled activities against opportunistic plant pathogens Alternaria alternata and Alternaria tenuissima with IC50 $197.75 \mu \mathrm{g} / \mathrm{ml}$ and $154.22 \mu \mathrm{g} / \mathrm{ml}, 116.89 \mu \mathrm{g} / \mathrm{ml}$ and $168.22 \mu \mathrm{g} /$ $\mathrm{ml}$ respectively, for oleic acid and palmitic acid [63]. The stem bark of $B$. ramiflora revealed mild effectiveness with zone of inhibition of $10 \mathrm{~mm}$ against Candida arrizae in comparison to griseofulvin (13$18 \mathrm{~mm})$ [49].

\section{Anti-inflammatory activity}

B. ramiflora is known to be effective against inflammation, which is confirmed by investigating the anti-inflammatory effect using methanolic extract of their stem, leaves and fruit pulp by carrageenan induced paw oedema method in rodents. The result indicated that the extracts of B. ramiflora at the dose level of $100 \mathrm{mg} / \mathrm{kg}$ and $200 \mathrm{mg} / \mathrm{kg}$ exhibited significant anti-inflammatory activity that was strongly comparable with the (Ibuprofen, $10 \mathrm{mg} / \mathrm{kg}$ ) [64]. Another study reported the down-regulating the increased level of cytokine due to inflammation effect of Baccaurea leaf on the cytokine level IL-1 $\beta$ ( $4.4 \mathrm{pg} / \mathrm{mg}$ protein) and TNF- $\alpha(0.21 \mathrm{ng} / \mu \mathrm{g}$ protein). The proposed anti-inflammatory bioactivity of leaf might be due to the presence of rosmarinic acid [44] and $\beta$-sitesterol which are established anti-inflammatory compounds [65-66]. B. courtallensis leaf extract has also been reported to be effective against inflammation at doses of $150 \mathrm{mg} / \mathrm{kg}$ and $450 \mathrm{mg} / \mathrm{kg}$ bodyweight, demonstrated substantial inhibition of carrageenan-induced rat paw edema formation compared to the standard drug Indomethacin $(10 \mathrm{mg} / \mathrm{kg})$ [30].

\section{Anti-cancer activity}

Cancer is a leading cause of death worldwide. According to the literature, the best anticancer activity was exhibited by hexane extract of B. motleyana peels that showed IC50 $43.6 \mu \mathrm{g} / \mathrm{mL}$ on colon cancer line (HT-29) compared to other extracts, measured by MTS assay [41]. B. macrophylla is also considered as the potential source for anticancer activities against human cervical cancer cell line (HeLa cells), human colon cancer cell lines (HT29 and HCT116 cells), human breast cancer cell line (MCF-7 cells), and a non-cancer cell line (African green monkey kidney epithelial cells; Vero cells) were determined using the MTT assay, where the dried leaf ethanolic extract of B. macrophylla exhibited significant toxicity to HeLa, HT29 and HCT116 cells growth [17]. 


\section{Anti-hyperlipidemic activity}

Methanolic extract (200 and $400 \mathrm{mg} / \mathrm{kg}$ ) of B. courtallensis produced impressive antihyperlipidemic activity in Triton WR-1339 and high fat diet-induced hyperlipidemic rats, altered the serum levels of total cholesterol, triglycerides, high-density lipoprotein cholesterol and low-density lipoprotein cholesterol to near normal [32]. B. ramiflora is also known to be effective against hyperlipidemia, which is confirmed by investigating methanolic and ethanolic extracts of their leaf and seeds in alloxan-induced diabetic wistar rats. The result indicated that the extracts of $B$. ramiflora at the dose level of $150 \mathrm{mg} / \mathrm{kg}, 200 \mathrm{mg} / \mathrm{kg}, 250 \mathrm{mg} / \mathrm{kg}$ and $500 \mathrm{mg} / \mathrm{kg}$ bodyweight, extremely diminished levels of triglycerides, total cholesterol, (LDL)-cholesterol, and (HDL)-cholesterol and exhibited significant hypolipidimic activity that was strongly comparable with Metformin (100mg/kg/day) and Rosuvastatin (10mg/kg) [45-46].

\section{Analgesic activity}

Methanolic extract of fruit pulp and seeds of B. ramiflora were screened for analgesic activity by employing different animal models stating chemical (acetic acid induced writhing and formalin test), and physical (tail immersion) methods. Ibuprofen, morphine, and diclofenac sodium at the concentration of $10 \mathrm{mg} / \mathrm{ml}$ were used as standard. The result indicated that the extracts of $B$. ramiflora at doses of $200 \mathrm{mg} / \mathrm{kg}$ and $400 \mathrm{mg} / \mathrm{kg}$ bodyweight, significantly inhibited induced pain. Due to these excellent pharmacologically active analgesics of B. ramiflora can manage both central and peripheral pain in used animal models [24,64].

\section{Cytotoxic property}

Almost entire plant has been accessed for cytotoxic activity of $B$. ramiflora $[51,64,67,68]$. Among them the stem bark of $B$. ramiflora was found to be the best cytotoxic activity, which was investigated by using brine shrimp lethality bioassay, where the result showed that aqueous soluble fraction of stem bark of B. ramiflora exhibited most toxicity with LC50 $1.44 \mu \mathrm{g} / \mathrm{mL}$ as compared to the standard vincristine sulphate (LC50 0.9258 $\mu \mathrm{g} / \mathrm{mL}$ ) [51].

\section{Hypoglycemic effect}

A literature review revealed that methanolic extract of $B$. ramiflora leaves $(200 \mathrm{mg} / \mathrm{kg})$ as a single dose per day to the alloxan induced $(120 \mathrm{mg} / \mathrm{kg})$ diabetic rats for 14 days produced substantial hypoglycemia and reduced the elevated blood glucose level $(50.06 \%)$. The result was comparable with the standard metformin (58.17\%) [45]. The methanolic extract of the bark of B. ramiflora showed significant hypoglycemic activity with a significant $24.89 \%$ and $29.19 \%$ inhibition at $200 \mathrm{mg} / \mathrm{kg}$ and $400 \mathrm{mg} / \mathrm{kg}$ bodyweight, respectively [46].

\section{Cytoprotective effect}

Plant extracts having antioxidant activities also lead to the inhibition of oxidative damage to biological structures. Due to such antioxidant potential, the in vitro and in vivo cytoprotective effect of B. angulata juice was measured on plasma MDA levels in rabbits. They showed that B. angulata fruit significantly decreased the plasma level of MDA and increased the activities of superoxide dismutase, glutathione peroxidase and catalase in rabbits fed a high-cholesterol diet. Thus $B$. angulata protects Low-Density Lipoprotein (LDL) from oxidative modification may be attributed to phenolic compounds known to act as powerful chain-breaking antioxidants and free radical scavengers [14].

\section{Anti-diarrhoeal activity}

The protection and effectiveness of $B$. ramiflora fruit pulp and seeds were evaluated for in vivo castor oil induced anti-diarrheal activity against diarrhea. It is evident that the percentage inhibition of defecation by methanol extract $(200 \mathrm{mg} / \mathrm{kg})$ of fruit pulp was close to that of loperamide $(3 \mathrm{mg} / \mathrm{kg})$, while the seeds $(200 \mathrm{mg} / \mathrm{kg})$ were marginally more effective. Thus, it demonstrated anti-diarrheal activity [64].

\section{Sleep inducing property}

Melatonin is involved in circadian rhythm and regulation of diverse body functions, including sleep [69]. Melatonin was extracted by using solid phase extraction and showed a modest amount of melatonin (43.2 ng/g of dry sample weight) in B. ramiflora. Melatonin content in the leaves is a promising result for future development of this overlooked part of B. ramiflora as a health food supplement [70].

\section{Thrombolytic activity}

To identify blood thinning medications from plant source different extractives (aqueous, methanolic, ethanolic, ethyl acetate, chloroform, and their cyclohexane soluble partitioning materials extracts) of B. ramiflora were studied for thrombolytic activity. The aqueous extract of $B$. ramiflora seeds showed the highest thrombolytic potential with promising clot disruption (88.21\%) which was higher than the standard drug streptokinase (66.77\%) [68]. Another thrombolytic evaluation of $\mathrm{n}$-hexane extracts of $B$. ramiflora bark showed $17.00 \pm 1.31 \%$ of clot lysis, whereas streptokinase exhibited $65.13 \pm 0.96 \%$ of clot lysis as standard [71]. From these experiments, it can be said that the B. ramiflora extracts can be used as thrombolytic agents with its best pharmaceutical possibilities.

\section{Anti-atherosclerotic effect}

Atherosclerotic diseases are still major causes of mortality globally. $B$. angulata is claimed to be plaque-reducing activity as a new anti-atherogenic plant which was investigated by using in vivo animal model, where the result showed that treatment with fruit juice of $B$. angulata reduced plaque formation in rabbits' entire aorta thus decrease serum IL-8 and IL-18 production of inflammatory biomarkers and thus could protect against oxidative stress linked atherosclerosis and decrease the atherogenic index [72-73]. 


\section{Anthelmintic activity}

B. ramiflora possess varying degree of in vitro anthelmintic activity conducted by solitary study. The acetone extract of leaf $(100 \mathrm{mg} / \mathrm{ml})$ exhibited significant wormicidal activity against Pheretima posthuma in a dose-dependent manner, where the results were expressed in terms of time for paralysis and time for death of worms which was comparable to standard drug albendazole $(10 \mathrm{mg} / \mathrm{ml})$ [68]. The anthelmintic effect of leaf might be attributed to the presence of $\beta$-sitosterol, which has proven antihelimintic property [74].

\section{Insecticidal activity}

Insecticidal activity of acetone fraction $B$. ramiflora leaf has been tested against adult Sitophilus oryzae. The fraction was effective in eliminating $S$. Oryzae, with a mortality rate of $80 \%$ and $100 \%$, thus helping to manage the rice weevil field population, $S$. Oryzae [75].

\section{Hepatoprotective activity}

B. ramiflora exhibited a hepatoprotective effect against alcohol and paracetamol induced hepatotoxicity which was confirmed by histopathological examination of the liver tissue of control and treated animals. Treatment with ethanolic extracts of $B$. ramiflora leaves $(100 \mathrm{mg} / \mathrm{kg}$ and $200 \mathrm{mg} / \mathrm{kg}$ ) can alter the level of biochemical parameters to the near normal levels almost comparable to the silymarin. So that it can be concluded that B. ramiflora possess hepatoprotective effect against alcohol and paracetamol-induced liver damage in rats [76].

\section{Haemolytic activity}

A literature review analyzed that the haemolytic activity of fruit juice of B. ramiflora using human erythrocyte. Fruit juice $(100 \mu \mathrm{l} /$ $\mathrm{ml}$ ) was declared safe to human erythrocyte since it exhibited negligible haemolytic activity (\% Haemolysis=5.69) compared to Triton $\mathrm{X}-100(100 \mu \mathrm{l} / \mathrm{ml})$ where \% Haemolysis is 60.28 as standard [52].

\section{Neuropharmacological activity}

Two different neuropharmacological models, named open field and whole cross test were used to study the CNS depressant activity of crude extaracts $(100 \mathrm{mg} / \mathrm{kg}$ and $200 \mathrm{mg} / \mathrm{kg}$ ) of B. ramiflora fruit pulp and seeds, respectively. Both the tests revealed that the extracts could reduce the locomotor activity which is a measure of Central Nervous System (CNS) depressant activity. The results were comparable to the standard diazepam [64,77].

\section{Antidiabetic activity}

A literature review revealed that $B$. racemosa leaf extract possesses mild to moderate antidiabetic property, which was experimented through in vitro antidiabetic assay, i.e., $\alpha$-amylase inhibition method. It was observed that, methanol and ethanol leaf extracts of
B. rasemosa exhibited similar potency of antidiabetic activity with $\mathrm{IC}_{50}$ values were $67.63 \pm 0.36 \mathrm{ppm}, 67.46 \pm 0.23 \mathrm{ppm}$, respectively where Acarbose drug used as standard with IC50 $23.48 \pm 0.35 \mathrm{ppm}$ [57].

\section{Phytochemical Investigation}

\section{Phytochemical screening}

Preliminary phytochemical sampling of the genus Baccaurea disclosed the presence of many bioactive materials of terpenoids, glycosides, reducing sugar, phenols, flavonoids, alkaloids, phenols, tannins, steroids, flavonoids, volatile oils, quinones, coumarins, carbohydrates, anthraquinones, polyphenols, Ascorbic acids, phytosterols, gums and mucilage, saponins, proteins and fixed oils, phlobatannin, resins, organic acids, carotenoids from different crude alcohol and aqueous extracts of B. courtallensis, B. ramiflora, B. motleyana, B. lanceolata, B. macrocarpa and B. angulata. In B. ramiflora, the total polyphenilic content of the leaf extract was found $79.06 \pm 0.03 \mathrm{mg}(\mathrm{GAE}) / \mathrm{g}, 28.80 \pm 0.01 \mathrm{mg}(\mathrm{QE}) / \mathrm{g}$ flavonoid and $29.42 \pm 0.01 \mu \mathrm{g}$ cathechin equivalent/g proanthocyanidin respectively [44], similarly the total phenolic content was $51.4 \mathrm{mg}$ of GAE/g [78]. In B. angulata, the total phenolic content was $16.58 \mathrm{mg}$ $\mathrm{GAE} / \mathrm{g}$, flavonoid $31.05 \mathrm{mg} \mathrm{QE} / \mathrm{g}$ and anthocyanin 0.72 (mgc-3$\mathrm{g} / 100 \mathrm{~g}$ ) [58]. B. macrocarpa pericarp contained the total phenolics, total flavonoid, total anthocyanin, and total carotenoid with the values of $60.04 \pm 0.53 \mathrm{mg} \mathrm{GAE} / \mathrm{g}, 44.68 \pm 0.67 \mathrm{mg} \mathrm{CE} / \mathrm{g}, 1.23 \pm 0.20 \mathrm{mg}$ c-3-gE/100g and $0.81 \pm 0.14 \mathrm{mg} \mathrm{BCE/g} \mathrm{[53].} \mathrm{In} \mathrm{B.} \mathrm{rasemosa,} \mathrm{pulp} \mathrm{has}$ the highest Total Phenolic Content (TPC) and Total Flavonoid Content (TFC) with values $42.975 \pm 1.978 \mathrm{mg}$ (mg GAE g-1 dry extract) and $122.813 \pm 1.604 \mathrm{mg}$ (mg RE g-1 dry extract), respectively [55].

\section{Identification and isolation of bioactive compound}

A variety of bioactive constituents are present in B. ramiflora contributed to the discovery and characterization of many secondary metabolites. Literature search showed that $4^{\prime}$-0-(6-0-vanilloyl)- $\beta$-D-glucopyranosyl tachioside D (1), 6 ' ovanilloylpicraquassioside D (2), 6'-O-vanilloylicariside B5 (3) blumenol A (4), icariside B5 (5), 6'-0-vanilloylisotachioside (6), and $\beta$-sitosterol (7), 6'- 0-vanilloyltachioside (8), (-)-epicatechin (9), bis(8-catechiny 1)methane (Structure not found), aviculin (10), 3-0-caffeoyl-4-0-methylquinic acid (11), 5-0-caffeoylquinic acid methyl ester (12), tuberonic acid glucoside methyl ester (13), erigeside B (14), (2S,3S,4R)-2[(2R)-2-hydroxytetracosanoylamino]-1,3,4-octadecanetriol (15), aralia cerebroside (16), (24S)-24-ethylcholesta-3 $\beta, 5 \alpha, 6 \beta$-triol, stigmast-4-en-6 $\beta$-ol-3-one (17), 7-oxo- $\beta$-sitosterol (18), $7 \alpha$-methoxysigmast-5-en-3 $\beta$-ol (structure not found), daucosterol (19), rosmarinic Acid (20), epidihydrotutin (21), ramifloside (22), sapidolide A (23), picrotoximaesin (24), phytol (25), betulinic acid (26), oleic acid (27), palmitic acid (28), 3 methoxy 4 hydroxy-cinnamaldehyde (coniferyl aldehyde) (29), 3, 4, 5 trimethoxy cinnamaldehyde (30), 
3, 4, 5 trimethoxy benzaldehyde (31), 3,4 dimethoxy benzaldehyde (veratraldehyde) (32) and melatonin (N-acetyl-5-methoxytryptamine) (33) from different parts like leaf, stem, root, seed kernel and fruits of B. ramiflora (Figure 1) through HPLC, 1H and 1D, 2D, 13C- NMR spectroscopic methods, Various chromatographic techniques and GS- MS analysis [20,44,49,51,62,63,70,79-82].

According to the literature, (E)- Hex-2-enal (1) considered as the major active ingredient in $B$. motleyana fruits also contained high levels of methyl 2-hydroxy-3-methylbutanoate (2), methyl 2-hydroxy-3-methylpentanoate (3) and methyl 2-hydroxy-4-methylpentanoate (4) as an antibacterial activity. Secondary metabolites contained in rambai; Decanoic acid (5), 1- Decene (6), Methyl salicylate (7) and Stearyl alcohol (8) (Figure 2) were analysed by capillary GC and GC-MS [83-84]. Literature search showed that, three greatest antimicrobial compounds (Figure 3) including Dimethyl 2 , 3-bis [(trimethylsilyl)oxy] succinate (1), Arabino-hexos-2- ulose, 3, 4, 5, 6-tetrakis-o-(trimethylsilyl)-, bis (dimethyl acetal) (2) and Bis(trimethylsilyl) 2,3- bis [(trimethylsilyl)oxy] succinate (3) were identified from the crude extract of B. lanceolata based on derivatised GC-MS analysis of the Milli-Q water fractions [9]. $\beta$-sitosterol was also reported to be detected from the ethyl acetate (fr. EtOAc) extracts of Fruits of B. lanceolata [85].

In two different studies expand that a total of 17 phenolic compounds contained in the skin, pulp, and whole fruit of methanolic extract of B. angulata (Figure 4). Among them, five flavonoids (15), ten phenolic acids (6-15) and two phenolic diterpenes (16-17) were reported to be isolated and identified as quercetin (1), catechin (2), kaempferol (3), rutin (4), myricetin (5), caffeic acid (6), cinnamic acid (7), p-coumaric acid (8), ferulic acid (9), gallic acid (10), 4-hydroxybenzoic acid (11), protocatechuic acid (12), salicylic acid (13), sinapic acid (14), vanillic acid (15), carnosol (16) and carnosic acid (17) were performed on Chromatographic analyses of (LCMS/MS) (AB Sciex, Toronto, Canada) coupled to Perkin Elmer Flexar FX15 (UHPLC) system operated by AB Sciex analyst software for instrument control, data acquisition and data analysis [33-34,58](Table 2?).
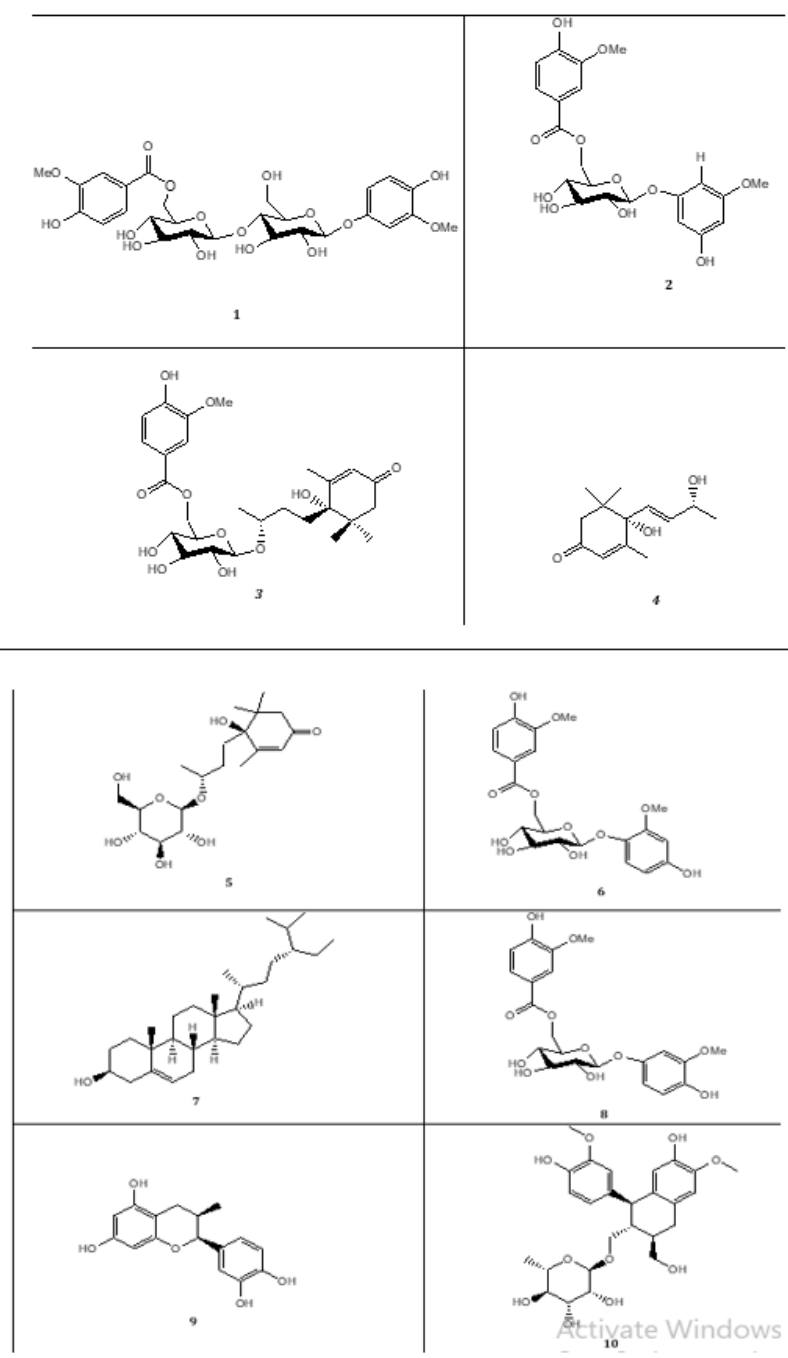

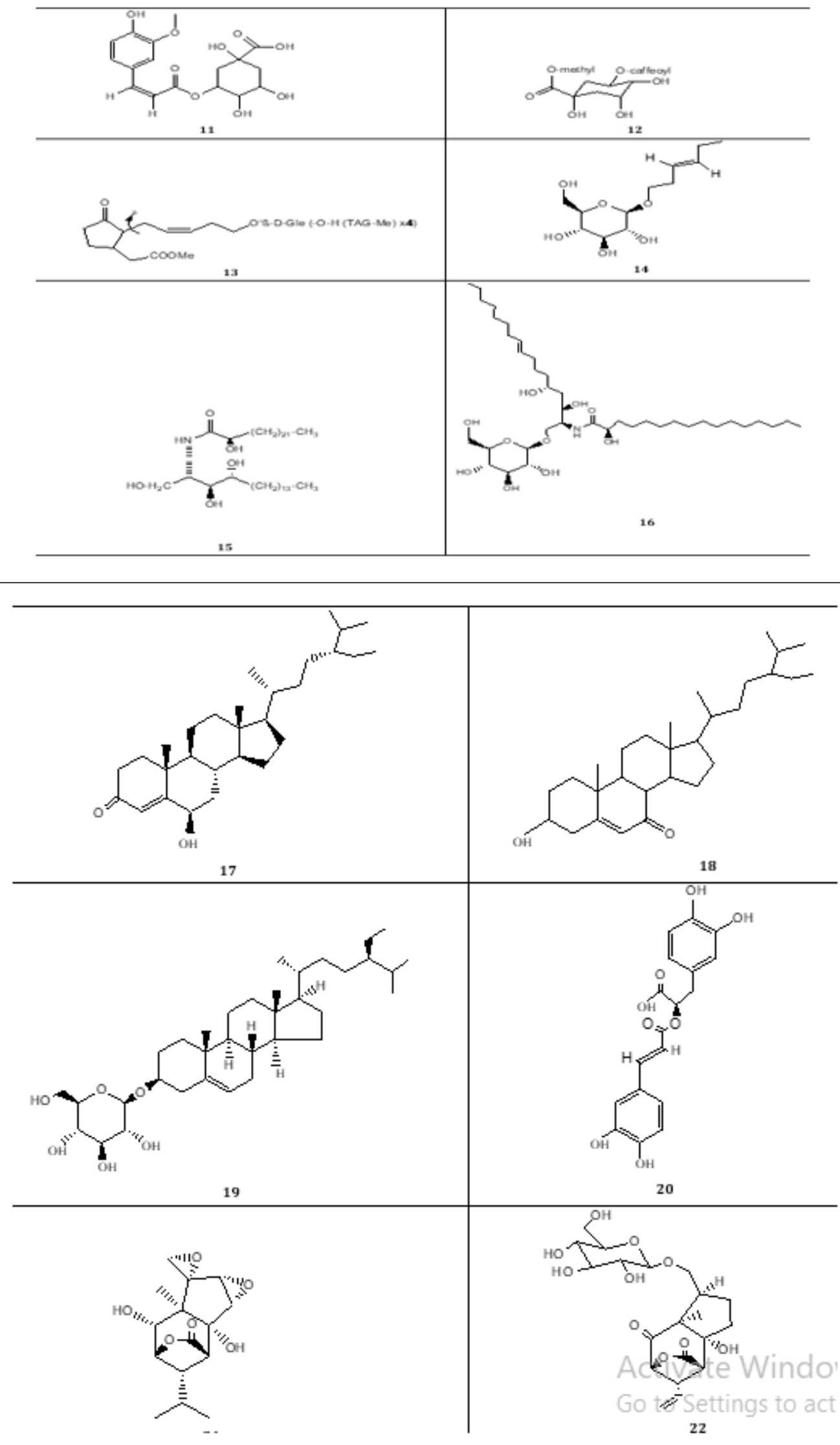

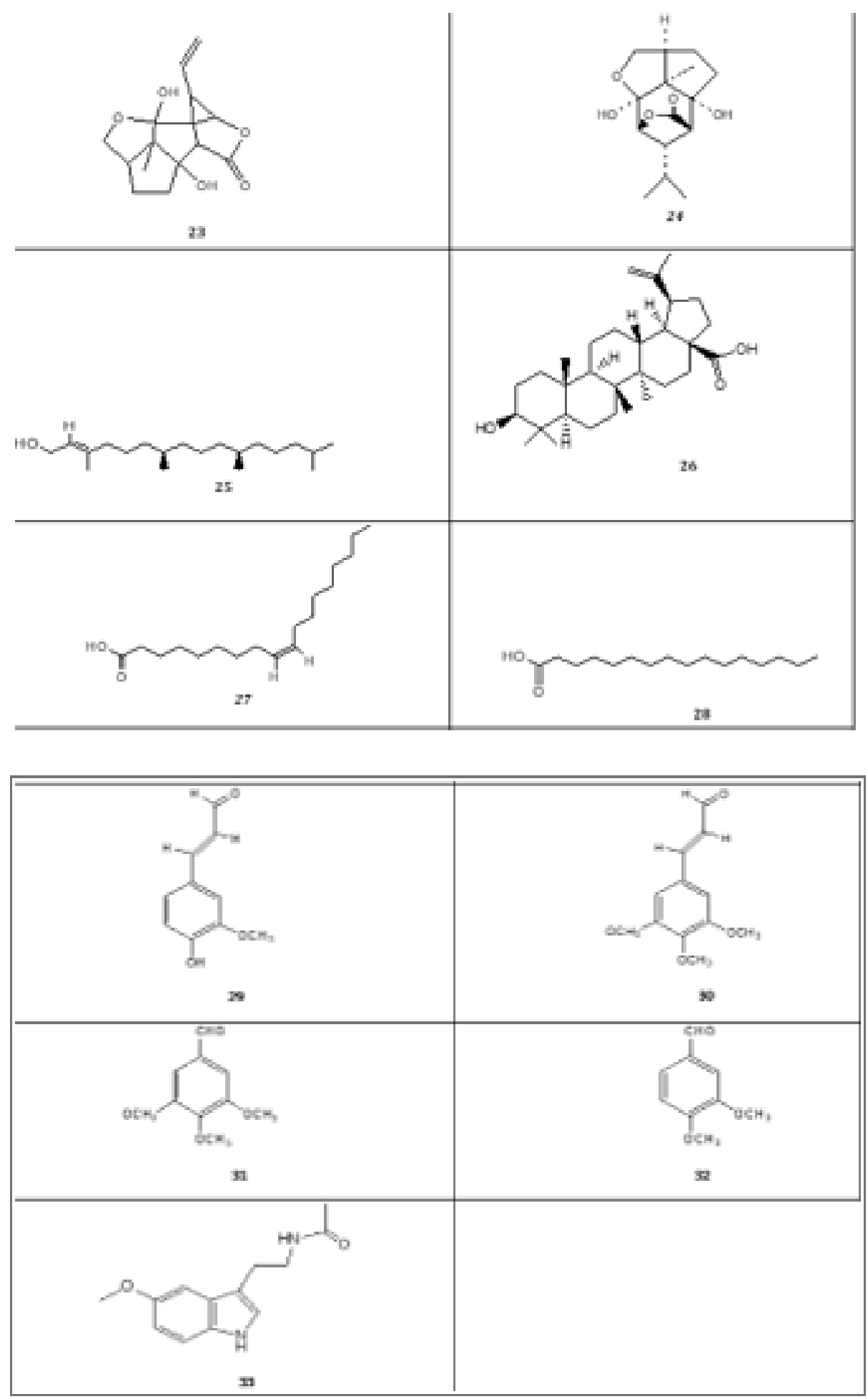

Figure 1: Isolated and identified bioactive constituents from B. ramiflora.

4'-O-(6-O-vanilloyl)-B-D-glucopyranosyl tachioside D (1), 6' Ovanilloylpicraquassioside D (2), 6'-O-vanilloylicariside B5 (3) Blumenol A (4), Icariside B5 (5), 6'-O-vanilloylisotachioside (6), and $\beta$-sitosterol (7), 6'- O-vanilloyltachioside (8), (-)-Epicatechin (9), Aviculin (10), 3-O-Caffeoyl-4-Omethylquinic acid (11), 5-O-caffeoylquinic acid methyl ester (12), Tuberonic acid glucoside methyl ester (13), Erigeside B (14), (2S,3S,4R)-2[(2R)-2-hydroxytetracosanoylamino]-1,3,4-octadecanetriol (15), Aralia cerebroside (16), stigmast-4-en-6ß-ol-3-one (17), 7-oxo- $\beta$-sitosterol (18), daucosterol (19), rosmarinic Acid (20), epidihydrotutin (21), ramifloside (22), sapidolide A (23), picrotoximaesin (24), phytol (25), betulinic acid (26), oleic acid (27), palmitic acid (28), 3 methoxy 4 hydroxy-cinnamaldehyde (coniferyl aldehyde) (29), 3, 4, 5 trimethoxy cinnamaldehyde (30), 3, 4, 5 trimethoxy benzaldehyde (31), 3,4 dimethoxy benzaldehyde (veratraldehyde) (32) and Melatonin (33). 


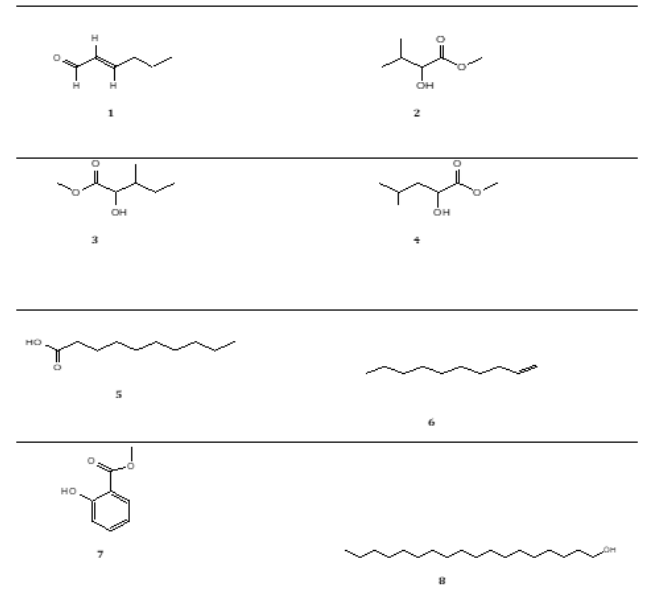

Figure 2: Isolated and identified secondary metabolites contained in B. motleyana fruits.

(E)-Hex-2-enal (1), methyl 2-hydroxy-3-methylbutanoate (2), methyl 2-hydroxy-3-methylpentanoate (3), methyl 2-hydroxy-4-methylpentanoate (4), Decanoic acid (5), 1-Decene (6), Methyl salicylate (7) and Stearyl alcohol (8).

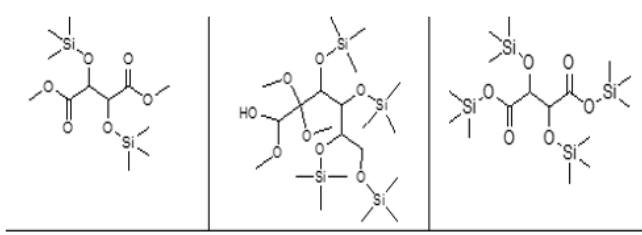

Figure 3: Antimicrobial compounds detected from B. lanceolata. Dimethyl2,3-bis[(trimethylsilyl)oxy] succinate (1), Arabino-hexos-2-ulose,3,4,5,6tetrakis-o-trimethylsilyl)-, bis (dimethyl acetal) (2) and Bis(trimethylsilyl) 2,3- bis[(trimethylsilyl) oxy] succinate (3).
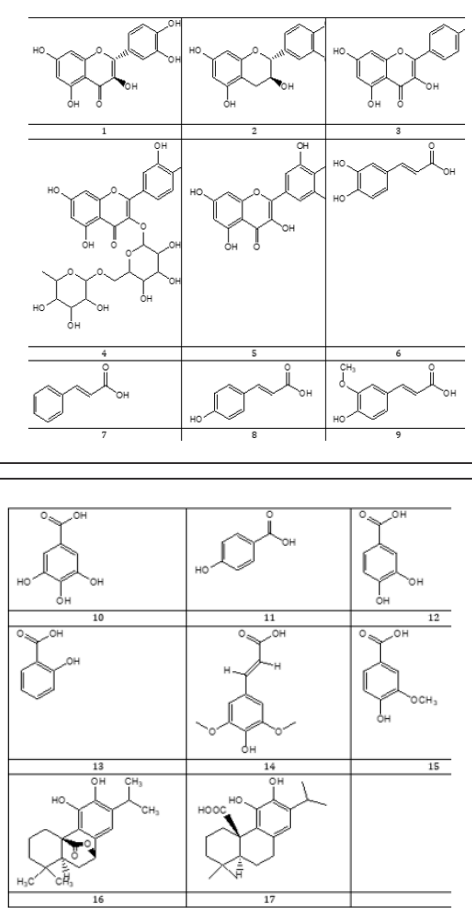

Figure 4: Isolated phenolic compounds from B. angulata. quercetin (1), catechin (2), kaempferol (3), rutin (4), myricetin (5), caffeic acid (6), cinnamic acid (7), p-coumaric acid (8), ferulic acid (9), gallic acid (10), 4-hydroxybenzoic acid (11), protocatechuic acid (12), salicylic acid (13), sinapic acid (14), vanillic acid (15), carnosol (16) and carnosic acid (17). 
Table 2: Bioactive compounds isolated from Baccaurea genus along with their activity.

\begin{tabular}{|c|c|c|c|c|}
\hline Species & Compound Isolated Plant Parts & Bioactive Compound & Activity & References \\
\hline \multirow{21}{*}{$\begin{array}{l}\text { B. rami- } \\
\text { flora Lour. } \\
\text { Muell. Arg }\end{array}$} & Stem & $\begin{array}{c}4^{\prime}-0-(6-0-\text { vanilloyl })-\beta-D-\text { glucopy- } \\
\text { ranosyl tachioside D }\end{array}$ & $\begin{array}{l}\text { Antioxidant ac- } \\
\text { tivity, Antili-pox- } \\
\text { ygenase activity }\end{array}$ & {$[80,86]$} \\
\hline & \multirow{3}{*}{ Leaves } & $6^{\prime}-0$ vanilloylisotachioside & \multirow{3}{*}{$\begin{array}{l}\text { Antioxidant } \\
\text { activity }\end{array}$} & \multirow{3}{*}[20]{} \\
\hline & & 6'-0-vanilloylitachioside & & \\
\hline & & $\begin{array}{l}\text { 3-0-cafeoyl-4-0-methylquinic } \\
\text { acid }\end{array}$ & & \\
\hline & Stem & Blumenol A & Cytotoxic activity & {$[80,87]$} \\
\hline & Leaves, Stem & Icariside B5 & $\begin{array}{l}\text { Antioxidant } \\
\text { activity }\end{array}$ & {$[20,80,88]$} \\
\hline & Stem & 6'-O-vanilloylpicraquassioside D & $\begin{array}{l}\text { Antioxidant ac- } \\
\text { tivity, antili-poxy- } \\
\text { genase activity }\end{array}$ & {$[80,86]$} \\
\hline & Leaves & Aviculin & $\begin{array}{l}\text { Induces apopto- } \\
\text { sis, Antioxidant } \\
\text { activity }\end{array}$ & {$[20,89]$} \\
\hline & Leaves & $\begin{array}{l}\text { 5-O-cafeoylquinic acid methyl } \\
\text { ester }\end{array}$ & $\begin{array}{l}\text { Antioxidant activ- } \\
\text { ity, Anti-radical }\end{array}$ & {$[20,90]$} \\
\hline & Leaves & Erigeside B & $\begin{array}{l}\text { Peroxyl scaveng- } \\
\text { ing activity }\end{array}$ & {$[20,91]$} \\
\hline & Leaves & $\begin{array}{c}\text { Melatonin (N-acetyl-5-methoxy- } \\
\text { tryptamine) }\end{array}$ & $\begin{array}{l}\text { Sleep inducing } \\
\text { activity }\end{array}$ & {$[70]$} \\
\hline & Leaves & (-)-Epicatechin & $\begin{array}{l}\text { Anti-hyperlip- } \\
\text { idemia, Reduce } \\
\text { high pressure, } \\
\text { Antioxidant } \\
\text { activity. }\end{array}$ & {$[20,92-93]$} \\
\hline & Stem and leaves & Daucosterol & $\begin{array}{c}\text { Anti-cancerous, } \\
\text { Neuroprotective, } \\
\text { Apoptosis }\end{array}$ & [94-98] \\
\hline & Leaves & Rosamaric acid & $\begin{array}{l}\text { Anti-Inflammato- } \\
\text { ry activity }\end{array}$ & {$[44]$} \\
\hline & Seed kernel, Fruits & Sapidolide A & $\begin{array}{l}\text { Anti-fungal } \\
\text { activity. }\end{array}$ & {$[62,79]$} \\
\hline & \multirow{2}{*}{ Berries } & Ramifoside & \multirow{2}{*}{$\begin{array}{l}\text { Anti-fungal } \\
\text { activity. }\end{array}$} & \multirow{2}{*}[62]{} \\
\hline & & Picrotoximaesin & & \\
\hline & \multirow{2}{*}{ Fruits } & Palmitic acid & \multirow{2}{*}{$\begin{array}{l}\text { Anti-fungal } \\
\text { activity. }\end{array}$} & \multirow{2}{*}[63]{} \\
\hline & & Oleic acid & & \\
\hline & Stem bark & Phytol & $\begin{array}{l}\text { Antidepressant, } \\
\text { Anti-inflammato- } \\
\text { ry, Antimicrobial, } \\
\text { Cytotoxic, Antiox- } \\
\text { idant activity }\end{array}$ & $\begin{array}{c}{[20,49-50,64,99-} \\
100]\end{array}$ \\
\hline & Stem bark & Betulinic acid & $\begin{array}{l}\text { Anti-bacterial } \\
\text { activity }\end{array}$ & [49] \\
\hline $\begin{array}{c}\text { B. rami- } \\
\text { flora Lour. } \\
\text { Muell. } \\
\text {-Arg, } \\
\text { Baccaurea } \\
\text { lanceolata }\end{array}$ & Stem and leave; Leaves; Stem; Fruits. & $\beta$-sitosterol & $\begin{array}{l}\text { Antioxidant, } \\
\text { Anti-inflamma- } \\
\text { tory, Analgesic, } \\
\text { Anthelmintic. }\end{array}$ & $\begin{array}{c}{[20,74,78,80} \\
85,98,101-102]\end{array}$ \\
\hline \multirow{3}{*}{$\begin{array}{c}\text { Baccaurea } \\
\text { motleyana } \\
\text { (Muell. } \\
\text { Arg.) } \\
\text { Muell. }\end{array}$} & \multirow{3}{*}{ Fruits } & $\begin{array}{l}\text { Methyl 2-hydroxy-3-methylbu- } \\
\text { tanoate, }\end{array}$ & \multirow{3}{*}{$\begin{array}{l}\text { Antibacterial } \\
\text { activity }\end{array}$} & \multirow{3}{*}[83]{} \\
\hline & & $\begin{array}{l}\text { Methyl 2-hydroxy-3-methylpen- } \\
\text { tanoate, }\end{array}$ & & \\
\hline & & $\begin{array}{l}\text { Methyl 2-hydroxy-4-methylpen- } \\
\text { tanoate }\end{array}$ & & \\
\hline
\end{tabular}




\begin{tabular}{|c|c|c|c|c|}
\hline \multirow{3}{*}{$\begin{array}{l}\text { Baccaurea } \\
\text { lanceolata. }\end{array}$} & \multirow{3}{*}{ Fruits } & $\begin{array}{c}\text { Dimethyl 2, 3-bis[(trimethylsilyl) } \\
\text { oxy] succinate }\end{array}$ & \multirow{3}{*}{$\begin{array}{l}\text { Antimicrobial } \\
\text { activity }\end{array}$} & \multirow{3}{*}{ [9] } \\
\hline & & $\begin{array}{l}\text { Arabino-hexos-2- ulose, } 3,4,5 \text {, } \\
\text { 6-tetrakis-o-(trimethylsilyl)-, bis } \\
\text { (dimethyl acetal) }\end{array}$ & & \\
\hline & & $\begin{array}{c}\text { Bis(trimethylsilyl) 2,3- } \\
\text { bis[(trimethylsilyl)oxy] succinate }\end{array}$ & & \\
\hline
\end{tabular}

\section{Conclusion}

Medicinal Plants are the gift of nature to human beings to have a healthy life free of disease. In Southeast Asia, phytomedicine for local healers is very common with Baccaurea species. The numerous ethnomedicinal practices, phytochemical properties, pharmacological activities, and pharmaceutical applications of Baccaurea species have been demonstrated in this study. Phytochemical and pharmacological screening records of the various species of Baccaureas indicated the presence of important bioactive substances. A review is worthwhile due to the significance of the underutilized plants as a source of new medicinal agents. Therefore, for the production and creation of new drugs, more research and activities relating to the inventory, conservation, characterization, and isolation of the compound from the medicinally conspicuous Baccaurea plant species are required [86-106].

\section{Conflict of Interest Statement}

Authors announce that no conflict of interest occurs.

\section{Acknowledgements}

TKC gratefully acknowledges the support and expresses its appreciation to the Department of Pharmacy, Manarat International University, Ashulia Model Town, Khagan, Ashulia, Dhaka, Bangladesh for providing all the facilities and moral support to conduct the work.

\section{References}

1. MR Ali, M Hossain, JF Runa, M Hasanuzzaman (2013) Preliminary cytotoxic activity of different extracts of Averrhoa bilimbi (fruits). Int Curr Pharm J 2(3): 83-84.

2. S Akter, A Sarker (2015) Antimicrobial activities of seeds of Diospyros blancoi and Baccuarea ramiflora. Int J Adv Pharmacy Biol Chem 4(4) 789-793.

3. P Dey, I Pal, (2015) A Glimpse on Baccaurea ramiflora, A Less Appealing, Underutilized Medicinal Plat of West-Bengal (An Extensive Review). Int J Curr Res 7(7): 18289-18295.

4. PJ Houghton (1995) The role of plants in traditional medicine and current therapy. J Altern Complement Med 1(2): 131-143.

5. MS Uddin, Sarwar H, Abdullah Al, Devesh Tewari, Asaduzzaman, et al. (2018) Phytochemical analysis and antioxidant profile of methanolic extract of seed, pulp, and peel of Baccaurea ramiflora Lour. Asian Pac J Trop Med 11(7): 443-450.

6. KAwang, M Shukri, M Ali, (2018) Diversity, distribution, and conservation of Baccaurea species in the home gardens and orchards in Malaysia.

7. G Gunawan, T Chikmawati, S Sobir, S Sulistijorini, (2016) Review: Fitokimia genus Baccaurea spp. Bioeksperimen J Penelit Biol 2(2): 96.
8. P Haegens, (2000) Biogeography door pp1-216.

9. S Galappathie (2018) Investigation of antimicrobial activity and phytochemical characterisation of plant extracts. 1-195.

10.S. Galappathie, A Palombo, Chia Yeo T, SiokLey DL, Chu LeeTu, et al. (2014) Comparative antimicrobial activity of South East Asian plants used in Bornean folkloric medicine. J Herb Med 4(2): 96-105.

11. B Gogoi (2017) Baccaurea ramiflora Lour: Biochemical and ethnobotanical value with scope for bio-prospection. Ann Plant Sci 6(7): 1649.

12. Aiswarya KP, Sruthy UN, Mahesh S, Laija S Nair (2016) Phytochemical Analysis of Leaf, Bark and Fruit Extracts of Baccaurea courtallensis Muell. Arg. J Pharmacogn Phytochem 5(3): 196-198.

13. M Ayyanar, S Ignacimuthu (2010) Diversity, Conservation Status and Medicinal Plants of the Family Euphorbiaceae in Tirunelveli Hills, Southern India. J Exp Sci 1(6): 12-16.

14. MA Mikail, Adewale Ahmed, Md Ibrahim, Norazlanshah H, Md Syaiful B, et al. (2016) Baccaurea angulata fruit inhibits lipid peroxidation and induces the increase in antioxidant enzyme activities. Eur J Nutr 55(4): 1435-1444.

15. L Momand, Robiaza Z, Md Ibrahim, Maryam M, Tara Jalal et al. (2014) Antimicrobial Effect of Baccaurea angulata Fruit Extracts against Human Pathogenic Microorganisms. Med Aromat Plants 3(4): 3-7.

16. TK Tim, (2012) Edible medicinal and non-medicinal plants: Volume 4 Fruits. 4: 1-1022.

17. S Tisadondilok, T Senawong (2017) Antioxidant activities and anticancer screening of ethanolic extracts from Baccaurea macrophylla Muell and Elateriospermum tapos Blume. 12(5): 11-18.

18. M Farid Hossain (2017) Nutritional Value and Medicinal Uses of Minor Fruits: Burmese Grape (\&lt;i\&gt;Baccaurea ramiflora\&lt;/i\&gt; Lour.).Int J Nutr Food Sci 6(5): 211-214.

19. M Raghavan, Md Ramjan (2018) Burmese grape (Baccaurea ramiflora Lour.): A promising fruit crop for future generations. J Med Plants Studies 6(3): 50-52.

20. Xian Wen Y, Jun Song W, Yan Lin M, Hai Tao X, Yi Qing Z, et al. (2007) Bioactive phenols from the leaves of Baccaurea ramiflora. Planta Med 73(13): 1415-1417.

21. KA Goyal, T Mishra, A Sen, (2013) Antioxidant profiling of Latkan (Baccaurea ramiflora Lour.) wine. Indian J Biotechnol 12(1): 137-139.

22. D Kalita, J Saikia, AK Mukherjee, R Doley, (2014) An ethnomedicinal survey of traditionally used medicinal plants for the treatment of snakebite in Morigaon district of Assam, India. Int J Med Arom Plants 4(2): 97-106.

23. KA Zaman, AA Khalid (2015) Free radical scavenging activity of some bangladeshi medicinal plants. Pharmacologyonline 3: 29-32.

24.S Akter, T Majumder, R Karim, Z Ferdous, M Sikder (2015) Analgesic activities of Geodorum densiflorum, Diospyros blancoi, Baccaurea ramiflora and Trichosanthes dioica. J Pharmacogn Phytochem 4(3): 209-214.

25. A Choudhury, NA Patel, (2016) Pharmacognostical and physico-chemical studies of the bark of Baccaurea ramiflora lour. Int J Pharmacogn Phytochem Res 8(12): 1935-1939. 
26. A Abdullah, M Hossain, M Bhuiyan (2005) Propagation of Latkan (Baccaurea sapida Muell.Arg) by Mature Stem Cutting. J Agric Biol Sci 1(2): 129-134.

27. R Maharani, Anna S (2019) Preliminary phytochemical analysis and in vitro antioxidant activity of baccaurea courtallensis. Res J Pharm Technol 12(9): 4397-4399.

28. P Vazhacharickal, J Mathew, E George (2017) Phytochemical analysis of fruit extracts of Baccaurea courtallensis and evaluation of cholesterol lowering propertys.

29. De Britto, R Mahesh (2007) Evolutionary medicine of Kani tribal's botanical knowledge in Agasthiayamalai biosphere reserve South India. Ethnobot Leafl 11:280-290.

30. Md Jasim, M Suja, S Anusha, R Nair (2019) Analysis of antioxidant and anti-inflammatory potential of Baccaurea courtallensis (Wight) Mull Arg. J Pharmaco Phytochem 8(3): 3994-4000.

31. BS Babu (2019) Antioxidant activity of leaf and root extracts of Baccaurea courtallensis (Wight) Muell.-Arg Euphorbiaceae. Inter J Scient Res Rev 8(5): 112-122.

32. C Sunil (2017) Antihyperlipidemic and Antibacterial Activities of Baccaurea Courtallensis Leaves. Open Access J Pharm Res 1(3).

33. Idris A, Maryam AM, Md Ibrahim (2017) Baccaurea angulata fruit juice ameliorates altered hematological and biochemical biomarkers in dietinduced hypercholesterolemic rabbits. Nutr Res 42: 31-42.

34. I Ahmed, Maryam AM, Md Bin Ibrahim, Norazlanshah B, Syaiful Rasad, et al. (2015) Antioxidant activity and phenolic profile of various morphological parts of underutilised Baccaurea angulata fruit. Food Chem 172: 778-787.

35. Nurhazni KJ, Darina I, Md Ibrahim, Adros Yahy, Norazmir, et al. (2013) Proximate composition and antioxidant activity of dried belimbing dayak (Baccaurea angulata) fruits. Sains Malaysiana 42(2): 129-134.

36. S Sukmasari, AJ Qader, MN Rahman, M Ibrahim, AA Doolaanea (2018) The release profiles of baccaurea angulata extract from various gelling agents. J Pharm Sci Res 10(1): 45-50.

37. A Mu (2019) No Title J Chem Inf Model 53(9): 1689-1699.

38. AB Suwardi, ZI Navia, T Harmawan, Syamsuardi, E Mukhtar (2020) Ethnobotany and conservation of indigenous edible fruit plants in south Aceh, Indonesia. Biodiversitas 21(5): 1850-1860.

39. S Hadi, S Wahyuono, A Yuswanto, E Lukitaningsih (2017) SPF Test from Baccaurea lanceolata Muell.Arg Fruit Isolates. Indones J Cancer Chemoprevention 8(1): 38-41.

40. M Suhaila, H Zahariah, H Norhashimah (1994) Antimicrobial activity of some tropical fruit wastes (guava, starfruit, banana, papaya, passionfruit, langsat, duku, rambutan and rambai). Pertanika J Trop Agric Sci 17(3): 219-227.

41. M Ismail, G Bagalkotkar, S Iqbal, HA Adamu (2012) Anticancer properties and phenolic contents of sequentially prepared extracts from different parts of selected medicinal plants indigenous to Malaysia. Molecules 17(5): 5745-5756.

42. A Ferdoushi, S Mahmud, M Rana, M Islam, A Salauddin, et al. (2016) A Survey on Medicinal Plant Usage by Folk Medicinal Practitioners in Different Villages at Nalitabari Upazilla, Sherpur District, Bangladesh. European J Med Plants 11(3): 1-22.

43. A Mirfat, I Amin, K Kartinee, H Muhajir, M Shukri (2018) Underutilised fruits: a review of phytochemistry and biological properties. J Food Bioact 1(1): 2-30.

44. T Usha, S Middha, M Bhattacharya, P Lokesh, AK Goyal (2014) Rosmarinic acid, a new polyphenol from Baccaurea ramiflora Lour. leaf: A probable compound for its anti-inflammatory activity. Antioxidants 3(4): 830842.
45. OM Ullah, FK Urmi, AM Howlader, KM Hossain, TM Ahmed, et al. (2012) Extract of Baccaurea Ramiflora. Int J Pharm Pharm Sci 4(3): 266-269.

46. Y Alam, S Hossain, S Fakir, A Das, IJ Afia, et al. (2019) Hypolipidemic Effect of Ethanolic Seeds Extract of Baccaurea ramiflora in Wister Albino Rats. Inter Res J Pharm Med Sci 3(1): 25-27.

47. R Amin, MN Nabi (2015) Evaluation of cytotoxic and antioxidant activity of different fractions of methanolic extract of Baccaurea ramiflora (Lour.) fruits. Int Curr Pharm J 4(6): 386-389.

48. SI Keya, N Ahmed, MN Munni, N Al Masud, MM Runa, et al. (2018) Invitro investigation of Antioxidant activity of Baccaurea ramiflora in different fractions. Plants J 6(4): 100-103.

49. M Mandal, L Kabir, ST Haque, E Haque (2018) Bioresearch Communications Isolation of Bioactive Principles and Studies of Antimicrobial, Cytotoxic and Antioxidant Activities of the stem bark of Baccaurea ramiflora (Euphorbiaceae). 4(2): 565-571.

50. MT Islam, Leticia S, Márcia F, João Marcelo, Marcus Vinícius 0, et al. (2016) Preparation of phytol-loaded nanoemulsion and screening for antioxidant capacity. Int Arch Med 9: 1-15.

51. SD Puja, CM Hasan, M Ahsan (2020) Baccaurea ramiflora: Isolation of Aldehydes and in Vitro Biological Investigations. Sci Res 11(7): 147-157.

52. MR Saha, P Dey, TK Chaudhuri, AK Goyal, D Sarker, et al. (2016) Assessment of haemolytic, cytotoxic and free radical scavenging activities of an underutilized fruit, baccaurea ramiflora lour. (roxb.) muell. Arg. Indian J Exp Biol 54(2): 115-125.

53. MF Abu Bakar, NE Ahmad, FA Karim, S Saib (2014) Phytochemicals and antioxidative properties of borneo indigenous liposu (Baccaurea lanceolata) and tampoi (Baccaurea macrocarpa) fruits. Antioxidants 3(3): 516-525.

54.E Erwin, WR Pusparohmana, IP Sari, R Hairani, U Usman, (2018) Phytochemical and antioxidant activity evaluation of the bark of Tampoi (Baccaurea macrocarpa). F1000Research 7: 1-10.

55. L Permatasari, S Riyanto, A Rohman, (2019) Baccaurea racemosa (Reinw. ex Blume) Müll. Arg. pulp: A potential natural antioxidant. Food Res 3(6): 713-719.

56. H Widodo, S Sismindari, W Asmara, A Rohman, (2019) Antioxidant activity, total phenolic and flavonoid contents of selected medicinal plants used for liver diseases and its classification with chemometrics. J Appl Pharm Sci 9(6): 99-105.

57. L Wulandari, AS Nugraha, NP Azhari, (2020) Penentuan Aktivitas Antioksidan dan Antidiabetes Ekstrak Daun Kepundung (Baccaurea racemosa Muell.Arg.) secara In Vitro. J Sains Farm Klin 7(1): 60-66.

58. I Darina, N Hazali, N Jauhari, Md Nor Omar, Mohd Noor, et al. (2013) Physicochemical and antioxidant characteristics of Baccaurea angulata fruit juice extract. African J Biotechnol 12(34): 5333-5338.

59. IA Ahmed, Maryam A, Muhammad B, Norazlanshah B, Mohammad S, et al. (2014) In vitro Antioxidant Properties of Underutilized Baccaurea angulata Fruit. Int J Adv Agric Environ Eng 1(2).

60.S Mann, A Sharma, S Biswas, RK Gupta (2015) Identification and molecular docking analysis of active ingredients with medicinal properties from edible Baccaurea sapida. Bioinformation 11(9): $437-$ 443.

61. (2007) An Indian Journal Note. Anal Chem 6(2): 4-8.

62. ZH Pan, DS Ning, SS Huang, YF Wu, T Ding, et al. (2015) A new picrotoxane sesquiterpene from the berries of Baccaurea ramiflora with antifungal activity against Colletotrichum gloeosporioides. Nat Prod Res 29(14): 1323-1327.

63. M Bordoloi, Surovi S, Prasanta K, Bhaskor K, Partha P, et al. (2017) Isolation, characterization, and antifungal activity of very long chain alkane derivatives from Cinnamomum obtusifolium, Elaeocarpus lanceifolius and Baccaurea sapida. J Mol Struct 1142: 200-210. 
64. ML Nesa, S Sajedul, Khairunasa Api , Md Moklesur, Md Monirul, et al. (2018) Screening of Baccaurea ramiflora (Lour.) extracts for cytotoxic, analgesic, anti-inflammatory, neuropharmacological and antidiarrheal activities. BMC Complement. Altern Med 18(1): 35.

65. A Gomes, A Saha, I Chatterjee, AK Chakravarty (2007) Viper and cobra venom neutralization by $\beta$-sitosterol and stigmasterol isolated from the root extract of Pluchea indica Less. (Asteraceae). Phytomedicine 14(9) 637-643.

66. S Loizou, I Lekakis, GP Chrousos, P Moutsatsou (2010) $\beta$-Sitosterol exhibits anti-inflammatory activity in human aortic endothelial cells. Mol Nutr Food Res 54(4): 551-558.

67. MA Howlader, AS Apu, RK Saha, F Rizwan, N Nasrin, et al. (2012) Cytotoxic Activity of N-hexane, Chloroform and Carbon Tetrachloride Fractions of The Ethanolic Extract of Leaves and Steam of Baccaurea Ramiflora (Lour.). Ijpsr 3: 822-825.

68. K Masud, T Shishir, N Mahbub, M Hossain, N Islam, et al. (2018) Study of cytotoxic and thrombolytic activity of Boeica filiformis in different extracts. Int J Res Pharm Pharm Sci Int 3(4): 22-25.

69. M Ansari, R Kh, N Yasa, S Vardasbi, SM Naimi, et al. (2010) Measurement of melatonin in alcoholic and hot water extracts of Tanacetum parthenium, Tripleurospermum disciforme and Viola odorata. DARU J Pharm Sci 18(3): 173-178.

70. T Padumanonda, J Johns, A Sangkasat, S Tiyaworanant, (2014) Determination of melatonin content in traditional Thai herbal remedies used as sleeping aids. DARU J Pharm Sci 22(1):6.

71. A Khatun et al. (2016) Preliminary study on thrombolytic property of thirty-six different extracts of eight Bangladeshi medicinal plants with folkloric relevance. Orient Pharm Exp Med 16(4): 311-319.

72. MA Mikail et al. (2014) Changes in the Markers of Atherosclerosis Following Administration of Belimbing Dayak (Baccaurea Angulata) Fruit Juice in Experimental Rabbits Fed with Cholesterol Diet. Int J Adv Agric Environ Eng 1(2): 151-154.

73. M Ibrahim, MA Mikail, IA Ahmed, R Abdul Ghani (2018) Phenolicrich baccaurea angulata modulates inflammatory biomarkers of atherosclerosis. J Nutr Metab.

74. IM Villaseñor, J Angelada, AP Canlas, D Echegoyen, (2002) Bioactivity studies on $\beta$-sitosterol and its glucoside. Phyther Res 16(5): 417-421.

75. K Nuruddin, Z Morshed, MN Islam, M Hossain, MT Deeba, et al. (2018) Study of anthelmintic and Insecticidal activity of Baccaurea ramiflora plant in different extracts. Inter J Pharm 5(6): 157-161.

76. S Saha, TS Gouda, SV Srinivas, (2017) Hepatoprotective Activity of Ethanolic Extract of Baccaurea Ramiflora and Microcos Paniculata Against Alcohol and Paracetamol Induced Hepatotoxicity in Albino Rats. Int Res J Pharm 8(11): 145-152.

77. IJ Biosci (2020) Phytochemical and comparative biological studies of Baccaurea ramiflora (Lour) extract. 6655: 197-211.

78. D Prakash, G Upadhyay, C Gupta, P Pushpangadan, KK Singh (2012) Antioxidant and free radical scavenging activities of some promising wild edible fruits. Int Food Res J 19(3): 1109-1116.

79. M Bordoloi, Nabin C, Srinivasa M, Subhas C, Raj K, et al. (1996) Sapidolide A: An unprecedented spherical carbocyclic lactone from Baccaurea sapida seed kernels: Is it a meroisoprenoid? Tetrahedron Lett 7(37): 6791-6792.

80. XW Yang, Hong Ping, Yan Lin, Fang Wang, Y Qing Z, et al. (2010) Three new vanilloid derivatives from the stems of baccaurea ramiflora. Planta Med 76(1): 88-90.

81. D Ning, Y Wu, Z Pan, Hong L (2014) Chemical constituents of the stem and leaves of Baccaurea ramiflora. Guangxi Zhiwu Guihaia 34(2): 160166.
82. XU Jing, GU Hua, LN Qi, (2007) References: A new sesquiterpene lactone from root of Baccaurea ramiflora: Objective To study the chemical constituents in the root of Baccaurea ramiflora. Methods Abstract Various chromatographic techniques were used to separate and purif 1450-1452.

83. K Wong, S Wong, S Siew, D Tie, (1994) Volatile constituents of the fruits of lansium domesticum correa (Duku and Langsat) and baccaurea motleyana (Muell. Arg.) Muell. Arg. (Rambai). Flavour Fragr J 9(6): 319324.

84. H Halim et al. (2019) Metabolomics dataset of underutilized Indonesian fruits; rambai (Baccaurea motleyana), nangkadak (Artocarpus nangkadak), rambutan (Nephelium lappaceum) and Sidempuan salak (Salacca sumatrana) using GCMS and LCMS. Data Br. 23: 4-6.

85. K Nastiti, S Hadi, Terpenoid Isolation from Baccaurea lanceolata Muell. Arg Fruit 2(1): 27-32.

86. R Nasar, (2013) Antioxidant and Antilipoxygenase activities of novel organic compounds and metal complexes The Islamia University of Bahawalpur

87. X Liu, F Tian, HB Zhang, E Pilarinou, JL McLaughlin, (1999) Biologically active blumenol A from the leaves of Annona glabra. Nat Prod Lett 14(1): 77-81.

88. A Vassallo, Giuseppina C, Francesco D, Alessandra B, Rokia S, et al. (2006) New flavonoid glycosides from chrozophora senegalensis and their antioxidant activity. Nat Prod Commun 1(12): 1089-1095.

89. D Lee, Yong Hoon L, Kwang H, Bum Soo, Akida A, et al. (2020) Aviculin isolated from lespedeza cuneata induce apoptosis in breast cancer cells through mitochondria-mediated caspase activation pathway. Molecules 25(7): 1708.

90. C Indy Tamayose, E Santos, N Roque, L Costa Lotufo, J Pena Ferreira, (2019) Caffeoylquinic Acids: Separation Method, Antiradical Properties and Cytotoxicity. Chem Biodivers 16(7): e1900093.

91. H Nguyen, Y Ding, K Sang, K Bae, Young, (2008) Total peroxyl radicalscavenging capacity of the chemical components from the stems of Acer tegmentosum Maxim. J Agric Food Chem 56(22): 10510-10514.

92. M Gómez Guzmán, R Jiménez, M Sánchez, María José Z, Pilar G, et al. (2012) Epicatechin lowers blood pressure, restores endothelial function, and decreases oxidative stress and endothelin-1 and NADPH oxidase activity in DOCA-salt hypertension. Free Radic Biol Med 52(1): 70-79.

93. M Kluknavsky, P Balis, A Puzserova, J Radosinska, A Berenyiova, et al. (2016) (-)-Epicatechin Prevents Blood Pressure Increase and Reduces Locomotor Hyperactivity in Young Spontaneously Hypertensive Rats. Oxid Med Cell Longev pp6949020.

94. P Gao, Xiaopeng H, Tingting L, Guangsen Li, Xujun Yu, et al. (2019) Daucosterol induces autophagic-dependent apoptosis in prostate cancer via JNK activation. Biosci Trends 13(2): 160-167.

95. L Jiang, Xiao Y, Nian Y, Li Ren, Feng Z, et al. (2015) Daucosterol protects neurons against oxygen-glucose deprivation/reperfusion-mediated injury by activating IGF1 signaling pathway. J Steroid Biochem Mol Biol 152: $45-52$

96. C Zhao, Tiantian S, Lixin W, Yahui S, Like Qu, et al. (2015) Daucosterol inhibits cancer cell proliferation by inducing autophagy through reactive oxygen species-dependent manner. Life Sci 137: 37-43.

97. J Zeng, X Liu, X Li, Y Zheng, B Liu, et al. (2017) Daucosterol inhibits the proliferation, migration, and invasion of hepatocellular carcinoma cells via Wnt/ß-catenin signaling. Molecules 22(6): 826.

98. A Goyal, S Middha, T Usha, (2020) Baccaurea ramiflora Lour.: a comprehensive review from traditional usage to pharmacological evidence. Adv Tradit Med pp0123456789. 
99. L Basso, Hildebrando L, Germano A, Walter F, Icaro S, et al. (2005) The use of biodiversity as source of new chemical entities against defined molecular targets for treatment of malaria, tuberculosis, and T-cell mediated diseases-A Review. Mem Inst Oswaldo Cruz 100(6): 475-506.

100. C Kim, Hyun Joo L, Ji Hoon J, Yoon Hyeon K, Deok Beom J, et al. (2015) Activation of Caspase-9/3 and Inhibition of Epithelial Mesenchyma Transition are Critically Involved in Antitumor Effect of Phytol in Hepatocellular Carcinoma Cells. Phyther Res 29(7): 1026-1031.
101. A Baskar, S Ignacimuthu, G Paulraj, S Al Numair, (2010) Chemopreventive potential of $\beta$-Sitosterol in experimental colon cancer model-an In vitro and In vivo study. BMC Complement Altern Med 4(10): 24.

102. G Gunawan, T Chikmawati, S Sobir, S Sulistijorini, (2018) Distribution, Morphological Variation and New Variety of Baccaurea Angulata Merr. (Phyllanthaceae). Floribunda 6: 1. 